THE attacks on Lin Piao and Confucianism in China which began in August 1973 have now spilled over into the pages of Scientia Sinica, the distinguished English-language journal of Chinese science published in Peking. In the most recent issue (Vol. 17, No. 2) alongside papers on a Markov description of stationary turbulence, graptoloidea and graptodendroids and pathogens of rice black streak dwarf disease is a section entitled 'Criticising Lin Piato and Confucius; combating and preventing revisionism'. Three testimonies are presented of the absurdity of Confucius' saying 'only the highest who are wise, and the lowest, who are stupid, cannot be changed'. Lin Piao, at one time Mao's Defence Minister and widely believed to have been killed in a plane crash in Mongolia in September 1971 whilst attempting to flee to the Soviet Union, is accused of following Confucius and 'twaddling that knowledge was endowed by nature' and 'slandering the working people as philistines ... only caring for oil, salt, sauce, vinegar and firewood'.

The first paper, uncompromisingly entitled " "The Lowest, who are stupid" are the wisest while "The Highest, who are wise" are the most stupid" is by Tsai Tzu-chuan of the Laboratory for Electric Light Source, Shanghai. He was exercised in the early 1960s by the imperialists who gloated over the Chinese incapacity to make a highpressure mercury vapour lamp. How- for production, the class struggle and ever his group started from scratch scientific experiment' is illustrated by and within half-a-year had delivered his quest for growth of the peanut. the goods. This success greatly $\mathrm{His}$ first attempt to raise the yield of heightened the morale of the pro- his own village's crop of peanuts by letariat and smashed the imperialist importing the methods of a neighbourslander against China: "advanced archi- ing village actually decreased the yield tecture but backward lighting'-which, and he 'got snubbed'. Next year howit must be admitted, isn't heard too ever he studied the cycle of growth often these days. One in the eye for more closely-'I was, so to speak, Lin Piao who wanted to restore capital- living together with the peanuts'. Even- tually by removing earth round the basal parts of peanut plants he found he could raise the yield $25 \%$. This he concludes is the result of not fearing hardships, being bold to practise and ready to get to the bottom of the matter. Lin Piao would not have encouraged this as he thought that the working classes cared only about money, and would have restored landlords. But now millions are clapping hands for joy, so "let the reactionaries at home and abroad bark what they like.' Finally, Chao Pu-hü, a 'workerpeasant-soldier student' at Kirin Medical College describes his transformation from 'half-baked medical orderly' to 'people's medical officer'. He worked in a deaf-mute clinic and was intrigued by the failure of acupuncture in this field. The books said that there were forbidden zones, and that needles should only be inserted a restricted amount. Chao $\mathrm{Pu}$-hü perceived this as akin to the idealist apriorism of Liu Shao-chi, Lin Piao and other swindlers' and proceeded to experiment on himself with prodigious lengths of insertion. This warmed his his fascist rule. As Chairman Mao put throat up so he applied the same to a it 'Lifting a rock only to drop it on girl Wang Ya-chiu. Three days of the reactionary fool',

Next Yao Shih-chang of the Tuanchieh Production Brigade, Shantung, relates how Mao's saying that 'correct ideas come from the struggle treatment and she called out, for the first time in her life. 'Long live Chairman Mao!' Thus emboldened, he and his colleagues have cured more than 3,000 deaf-mutes in the last five years.

His last colourful words are-'Now those who had tried to check the advance of history as mantis shanks would a carriage were ground to pieces by the wheel of history, yet their reactionary ideology still stinks. We will thoroughly criticise their reactionary world outlook and carry the socialist revolution in the realm of the superstructure through to the end!' And so, on the next page, to a homogeneous denumerable Markov process. nuclear material contained in AEC facilities, while the AEC's Regulatory division will retain responsibility for safeguarding nuclear material held by the nuclear power industry.

The reorganisation is thus unlikely to disrupt a move, spearheaded by Senator Abraham Ribicoff, to place nuclear security on the same bureaucratic level as the safety of nuclear power plants and to force increased security within the nuclear industry. The move, in the shape of an amendment to a bill designed to split up the AEC into a Nuclear Safety and Licensing Commission and an Energy Research and Development Administration, would create a top-level bureau concerned solely with nuclear safeguards. The bill has now been passed by the Senate Government Operations Committee and it is awaiting full Senate action.

\section{Nature conservation}

THE Nature Conservancy Council, having devoted the first months of its existence to internal reorganisation and the task of disentangling itself from the arms of the Natural Environment Research Council, is now ready to turn its attentions outwards again.

At a meeting in London recently, the Director, Mr R. E. Boote, outlined the aims of the 'new' Nature Conservancy. According to the Nature Conservancy Council Act of 1973 the NCC is now required to provide advice to the government on the development and implementation of all policies for or affecting nature conservation in Great Britain. This has enormous implications for the NCC which they intend to take very seriously, now that they are an independent body.
Mr Boote promised that they would not hesitate to make public advice given to the government and disregarded when they felt that circumstances warranted such disclosure.

The NCC continues to manage the 300,000 acres of nature reserves under its control but has relinquished its research stations to NERC. The NCC now commissions the necessary research, mainly from NERC, on the Rothschild customer/contractor principle. When asked whether conflict might arise between the research carried out for the government for NERC and that commissioned by the $\mathrm{NCC}, \mathrm{Mr}$ Boote replied that as they had complete control over the commissioning of their own research they could always go elsewhere. The NCC is at present financed by a parliamentary grant which this year has been "sufficient". 